International Journal of Engineering \& Technology, $7(2.26)(2018)$ 102-108
International Journal of Engineering \& Technology
SPC
Website: www.sciencepubco.com/index.php/IJET
Research paper

\title{
Weighted Product and Its Application to Measure Employee Performance
}

\author{
Nur Aminudin ${ }^{1}$, Eni Sundari ${ }^{1}$, Shankar K. ${ }^{2}$, P. Deepalakshmi ${ }^{3}$, Fauzi $^{1}$, Rita Irviani ${ }^{1}$, Andino Maseleno ${ }^{1 *}$ \\ ${ }^{1}$ Department of Information System, STMIK Pringsewu, Lampung, Indonesia \\ ${ }^{2}$ Assistant Professor, School of Computing, Kalasalingam Academy of Research and Education, Krishnankoil, Tamilnadu, India. \\ ${ }^{3}$ Professor, School of Computing, Kalasalingam Academy of Research and Education, Krishnankoil, Tamilnadu, India. \\ *Corresponding author E-mail: andimaseleno@gmail.com
}

\begin{abstract}
The decision support system of employee performance index appraisal is a decision support system that can assist decision makers for employee performance appraisal at the Pringsewu district revenue department. As for the purpose of this DSS namely 1 . To make decisions in the field of human resources to come, 2. To evaluate the performance of each employee in achieving the target work that has been determined , 3. For improve employee performance in the future. The problems to be solved are: 1 . How to change the assessment process that used to still use manual way by computerization. 2. How to apply the progress of change in today's sophisticated technology. In this decision system using Weighted Product (WP) weighting method of WP method is the choice of method on decision support system of employee performance appraisal index at revenue department of Pringsewu district. Weighted product method is a method of completion by using multiplication to attribute attribute rating in which rating must be prefixed with bob ot attribute in question. This decision support system can perform the process of calculating employee performance appraisal so that it can realize a fair assessment based on existing criteria calculations on this system using weighted product weighting (WP) that can produce the best employee performance appraisal system calculation from the highest value of 0.250 to the lowest value of 0.133 . The highest score is the best employee while the lowest score is the worst employee performance. This system can present employee performance appraisal reports quickly and clearly so that more effective and efficient.
\end{abstract}

Keywords: Decision-Making System, Employee, Performance Index, Weighted Product

\section{Introduction}

\subsection{Background}

An organization or agency cannot be separated from the role of human resources (HR) working in it. The quality of human resources is one of the factors needed to improve the productivity of an institution's performance. Therefore, an organization or agency needs to make an assessment of the performance of its employees. One of them is the assessment of employee performance index at the Pringsewu district revenue service [1] to know the potential of each employee in the agency conducted an assessment of the performance of the employee and provide an understanding of the importance of mapping the potential and quality of employees. Assessment is an effort made in making decisions on something of good measure bad qualities that are qualitative [2].

Good management of an organization to human resources can affect the success of the company's work. Placement Appropriate Position and Performance appraisal is one example of managing an organization/ company against its Human Resources [3]. Employee performance has a positive influence on the assessment of employee performance index and motivation have a positive effect on performance appraisal and employee performance. This study will examine the effect of performance appraisal on employee performance index with motivation as weighted product weighting that has been tested previous. The difference of this study with previous research is that this research performs testing in some information technology with weighted weigh ted product [4]. In this organization the performance of employees has a very important role in carrying out its function in the framework of organizational progress. Every individual is inside organizations must be able to be utilized as well as possible so as to provide maximum results. Where the success of the organization is very dependent on the role of employees in it because of employees as a potential resource and a source of power for moving the wheel of organizational activity [5].

The system that runs on the revenue department in Pringsewu district in the appraisal of employee performance is the employee performance appraisal process still done manually and the data processing has not been using the application program in take a decision but still use using Microsoft Excel in processing so that data takes considerable time long. In addition, the assessment is still subjective and not relevant to the actual situation so it cannot be used as a basis objective decision making and the revenue service difficulties in determining the best value employee performance [1]. During the decision-making process there is weighting by weighted product method to solve the employee performance index appraisal problem In addition, some criteria may have qualitative structures or have uncertain structures and cannot be measured appropriately. This method determines the weight value for each attribute, then proceeds with the assessment process that will select the alternatives the best employees [2]. 


\subsection{Formulation of the problem}

In the formulation of this problem how to make a model of decision making assessment of employee performance index on the revenue department that can help change the assessment process is done still using the manual way.

1. How to change the assessment process that used to be stillmanual way by computerization.

2. How to apply progress changes to today's sophisticated technology.

\subsection{Scope of problem}

In this study needed some boundary problem to fit with what was planned before the problem limitation in research namely generate a change in the employee performance index decision on the computerized revenue department that will result in a decision and generate an application that can provide decisions to the revenue agency in the appraisal process.

\section{4. Benefits of research}

The benefits of doing research namely helping the government in decision - making. assessment of employee performance index, assisting the design of information systems in decision making assessment of performance index with weighted product approach method, and assisting in the improvement of performance appraisal on the income department especially the employee performance can manage the income of regency Pringsewu district.

\subsection{Research purposes}

The objectives to be achieved in this research namely to make decisions in the field of human resources in the future, to evaluate the performance of each employee in achieving the work target that has been determined, to improve employee performance in the future.

\section{Literature Review}

\subsection{Decision Support System}

Decision Support System (DSS) is a computer application systems to assist decision makers in resolving them structured or unstructured. It provides environment for decision makers to analyze problems, build model, simulate processes and programs, and calls sources of information or analytical tools for decision makers [6]. Decision support system is an interactive information system that provides information, modeling and data manipulation. This system is used to help make decisions in semistructured and unstructured situations, where no one knows in general how decisions are made [7][8].

\subsubsection{DSS Characteristics}

An association number of the definition put forward regarding the definition and implementation of a CMS, causing there are many views on the system. DSS has the characteristics and abilities namely.

1. DSS combines data and model into one part. DSS is designed to assist managers in the decision-making process of semistructural problems.

2. DSS Provide support for managers' considerations rather than intended to replace manager functions.

3. DSS has interactive facilities that can facilitate the relationship between humans and computers.

4. Work by combining models and analytical techniques by entering existing data and functioning to search for information.
5. Serves to assist the process of personal assessment of decision-making to be the basis of decision-making.

\subsubsection{Stage of decision making}

To make a good decision there are several stages of the process that must be passed in decision making. Decision-making process through several stages, among others:

a. Stages of search. In this stage the decision maker learns the facts that occur, so we can identify the problems that occur. Usually performed an analysis of the system to its forming subsystem so that the output obtained in the form of a document statement of the problem.

b. Design Stage. In this stage the decision maker finds, develops, and analyzes all solutions, i.e. through modeling that can represent the real conditions of the problem. From this stage obtained the results of the form of alternative documents solution.

c. Choice Stage. In this stage the decision maker chooses one of the alternative solutions made at the design stage which is seen as the most appropriate action to overcome the current problem. From this stage obtained the solution document and implementation plan.

d. Implementation Phase. The decision maker runs the selected split action sequence in Choice. Successful implementation is marked by the answer to the problem faced, while the failure is marked still a problem that is being tried to overcome. From this stage obtained report on the implementation of the result solution.

\subsection{Employee performance}

Employee performance is the result or level of success of an employee as a whole within a certain period of time in performing the task compared to other things, such as the standard of work, target or criteria that have been determined beforehand and mutually agreed upon [9]. Performance comes from words job performance and also called actual performance or the actual performance or achievement that an employee has achieved. Many definitions or perceived performance by experts, one of the definitions of performance is the work that can be achieved by a person or group of people within an organization, in accordance with the authority and responsibility of each, in order to achieve the objectives of the relevant organization legal, unlawful, and in accordance with morals and ethics [10].

\section{Methodology}

\subsection{Method of collecting data}

Data collection methods are techniques or methods used to collect data. The method designates a method so that it can be shown its use through observation, literature study and interview [11]

The three data collection techniques used namely

a. Observation. Namely direct observation in the study of objects that will be used as a source of research data used by the author to collect data - the data [11]

b. Literature review. Collect data needed in development research derived from reference books on theoretical basis and technology to be used in design and development decision support system. [12].

c. Interview. This is one of the data collection conducted by way of question and answer or conversation directly with the parties concerned with the research undertaken. In this case the authors do question and answer to what employees of the revenue department. 


\subsection{Weighted Product Method}

The Weighted Product method is one of the methods of solving the MADM problem. This method evaluates several alternatives to a set of attributes or criteria, in which each attribute is independent of each other. Weighted product method uses multiplication techniques to attribute the attribute rating, where the rating of each attribute must be in advance with the corresponding attribute weights. This process is similar to the normalization process. This process Ai is given as following:

$$
S_{i}=\Pi{ }^{n}{ }_{j}=x_{i j} w j ; \text { with } \mathrm{i}=1,2, \ldots, \mathrm{m}
$$

Where $\Sigma w j=1 . \mathrm{Wj}$ is a positive rank to attribute a profit, and a negative value for the cost attribute. The relative preferences of each alternative are given as $\mathrm{i}$ :

$$
\begin{aligned}
& \Pi^{\mathrm{n}}{ }_{\mathrm{j}}= 1 x_{i j} w j \\
& V_{i}=: \text { with } 1=1,2, \ldots ., \mathrm{m} \\
& \Pi^{\mathrm{n}}{ }_{\mathrm{j}}=1\left(x_{j} *\right) w j
\end{aligned}
$$

Weighted Product Method use multiplication for connect attribute rating, where rating of each attribute must be removed first with the attribute weights in question [13].

\subsubsection{Weighted product method algorithm}

1. Determining the criteria to be used as a reference in the taking decision.

2. Specify each match rating alternative to each criterion.

3. Define the preference weight of each criterion.

4. Multiplying all attributes for a alternative with weight as rank positive attributes for profit and weight rank negatively for the cost attribute.

5. The multiplication result is summed to generates a value of $\mathrm{V}$ for each alternative.

6. Look for an alternative value by doing same steps as in step one, it's just using the highest value for each of the highest attributes for each attribute benefits and the lowest value for cost attribute.

7. Divide the $\mathrm{V}$ value for each alternative with the default value $(\mathrm{V}(\mathrm{A} *))$ produce

8. Finding alternative value. [14]

\subsubsection{The weighted value of the criteria}

The first step to be done in using the weighted product (WP) method for decision making assessment of employee performance index on the revenue service is to provide value on each alternative on any predetermined criteria. From each of these criteria will be determined its weight [14]. There are 5 criteria in employee performance appraisal decision making namely attendance, behaviour, experience, discipline, and team work.

Table 1: Attendance criteria

\begin{tabular}{ll}
\multicolumn{2}{c}{ Table 1: Attendance criteria } \\
\hline \multicolumn{1}{c}{ Value } & \multicolumn{1}{c}{ Weight } \\
\hline Very good & 1 \\
Good & 0.75 \\
Less & 0.5 \\
Bad & 0.25 \\
\hline
\end{tabular}

Table 1 shows the weight of attendance value to facilitate the next calculation step as one of the indicators of employee performance appraisal. From table there is weight of employee attendance value can be seen in table 1
Table 2: Behavior criteria

\begin{tabular}{ll}
\hline \multicolumn{1}{c}{ Value } & \multicolumn{1}{c}{ Weight } \\
\hline Very good & 1 \\
Good & 0.75 \\
Less & 0.5 \\
Bad & 0.25 \\
\hline
\end{tabular}

Table 2 shows the employee performance behavior criteria. Behavior is the process of how someone does something in an agency very much the behavior that appears that causes a certain result. Therefore a manager makes an assessment to find out which employee behavior is good and which employee behavior is bad. In Table 2 there is a weighting value to make it easier for managers to make decisions.

Table 3: Experience criteria

\begin{tabular}{lll}
\hline \multicolumn{1}{c}{ Value } & Weight \\
\hline Very good & 1 \\
Good & 0.75 \\
Less & 0.5 \\
Bad & 0.25 \\
\hline
\end{tabular}

In Table 3 shows the criteria of the experience value of the employee's value of a manager to assess the experience of his employees to find out how extensive employee knowledge of his work in Table 3 above is the weight of the criteria value of employee experience.

Table 4: Discipline criteria

\begin{tabular}{ll}
\hline \multicolumn{2}{c}{ Table 4: Discipline criteria } \\
\hline Value & Weight \\
\hline Very good & 1 \\
Good & 0.75 \\
Less & 0.5 \\
Bad & 0.25 \\
\hline
\end{tabular}

In table 4 shows the weight of the employee discipline criteria as an attitude or behavior that shows obedience to hours of work which includes the life and compliance of employees on working hours employees perform tasks in a timely and true.

Table 5: Team work criteria

\begin{tabular}{lll}
\hline \multicolumn{1}{c}{ Value } & \multicolumn{1}{c}{ Weight } \\
\hline Very good & 1 \\
Good & 0.75 \\
Less & 0.5 \\
Bad & 0.25 \\
\hline
\end{tabular}

Table 5 shows the weight of the value of team work to find out how far employees are able to do their jobs accurately or no errors

Table 6 shows that the table contains the priority of weight on each criterion. Helps simplify the calculation of predefined weighting criteria.

\begin{tabular}{c|c}
\multicolumn{2}{|c}{ Table 6: Weight values of each criterion } \\
\hline Weight & Criteria \\
\hline 30 & C 1 \\
20 & C 2 \\
15 & C 3 \\
10 & C 4 \\
25 & C 5 \\
\hline
\end{tabular}

\subsection{Frame of mind}

In this research is conducted for the development of decision making employee performance index. Figure 1 above explains the flow of the research methodology. This research begins with identifying the problem to be studied is about the decision making process assessment of employee performance index in the revenue service. The next step is studying about assessment method that will be used that is method of weighted product. Process then is 
doing the process of collecting data by observation method, literature study, and interview After the data collected then made the design the system is to develop a decision-making system. The next stage is creation and implementation of programs using visual basic programming language 6.0 and Microsoft access 2007 Process the end of this study is to test and evaluation of research results.

\section{Discussion}

\subsection{Weighted Product Settlement}

Manual calculation with weighted product based on the priority value of each criterion weight (W_init $j$ ) that has been determined how to calculate the value of weight improvement (W_Init $j$ ) that is

$$
W j=\frac{W_{-} \text {Initj }}{\sum_{j=1}^{n_{j} W_{-} \text {Initj }}}
$$

W1(Attendance)

$$
30+20+15+10+25
$$

$\mathrm{W} 1$ (Attendance) $=0,3$

$$
\begin{aligned}
& \mathrm{W} 2(\text { Behavior })=\frac{20}{30+20+15+10+25} \\
& \mathrm{~W} 2(\text { Behavior) }=0,2
\end{aligned}
$$

$$
15
$$

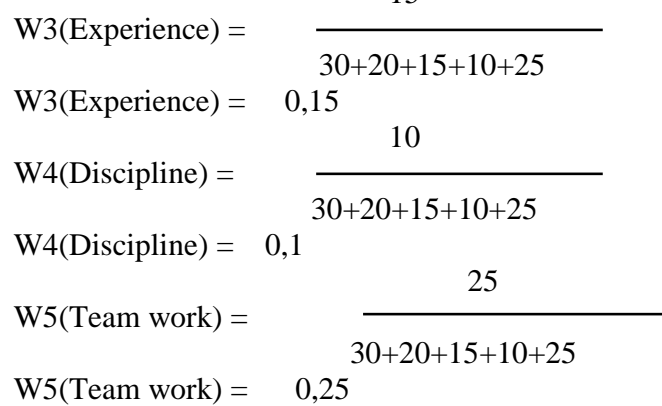

\subsubsection{Create weighting criteria table}

After determining the weight value $\mathrm{W}$, the next step is to create a table weighting employee performance criteria which will be selected 5 best employees to be shown in the following table.

\begin{tabular}{l|l|l|l|l|l}
\multicolumn{7}{c}{ Table 7: Weighting criteria } \\
\hline \multirow{2}{*}{ Alternative } & \multicolumn{5}{c}{ Criteria } \\
\cline { 2 - 6 } & \multicolumn{1}{c}{$\mathrm{C} 1$} & $\mathrm{C} 2$ & $\mathrm{C} 3$ & \multicolumn{1}{c}{ C4 } & C5 \\
\hline Santi & 1 & 0.75 & 0.75 & 0.5 & 0.75 \\
Tya & 0.75 & 0.25 & 1 & 0.75 & 0.5 \\
Eni & 1 & 0.75 & 0.75 & 1 & 0.75 \\
Gita & 0.75 & 0.5 & 0.25 & 0.75 & 0.75 \\
Aat & 0.75 & 1 & 0.75 & 0.75 & 1 \\
\hline
\end{tabular}

\subsubsection{Determination of vector value (SI)}

Calculating the Si vector, the existing data will be carried out with the weights of each criterion.

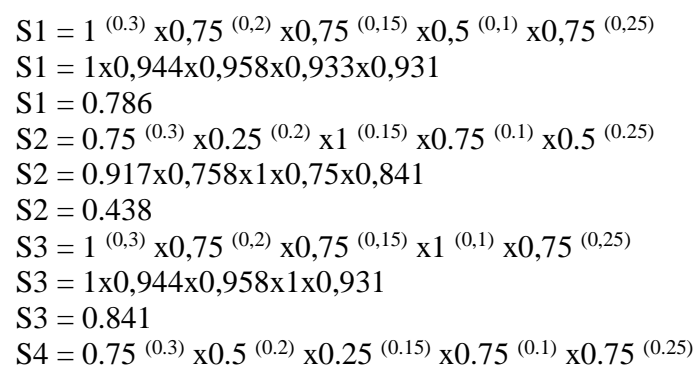

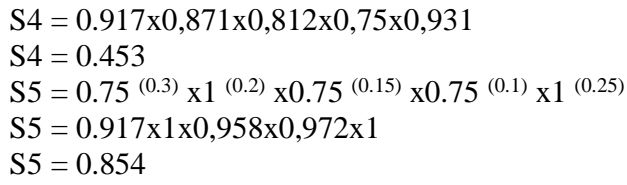

\subsubsection{Calculating the vector value (VI)}

Calculate the value of vector Vi by dividing the result of each vector $\mathrm{Si}$ by the sum whole $\mathrm{Si}$. How to calculate $\mathrm{Vi}$ vector is as follows:

$$
\begin{aligned}
& V i=\frac{S i}{\sum_{j=1}^{m} S i} \\
& \Sigma v i=0,786+0,483+0,841+0,453+0,854 \\
& \Sigma v i=3,417 \\
& \mathrm{~V} 1=\frac{0,786}{3,417=0,230} \\
& \mathrm{~V} 2=\frac{0,483}{3,417=0,141} \\
& \mathrm{~V} 3=\frac{0,841}{3,417=0,246} \\
& \mathrm{~V} 4=\frac{0,453}{3,417=0,133} \\
& \mathrm{~V} 5=\frac{0,854}{3,417=0,250}
\end{aligned}
$$

\subsection{System Design}

In the early opening of this decision-making system. the form that will come out the first time is the login form. User must enter a password to make employee performance appraisal decisions. Furthermore, employee data input form for decision making process employee performance appraisal. Form the process of calculating the weighted product to determine which employee performance is excellent or bad. Selection of the best employees. Results of decision making assessment of employee performance index.

\subsection{Implementation of the system}

It is a system implementation stage that will be performed if the system is approved including the program that has been made at the design stage of the system to be ready for operation [15].

\subsubsection{Login page}

The login page is the start page at the time the application starts. On this page the user must make the login process first before going into the main page. Incoming page views can be seen in the Figure 1 below. 

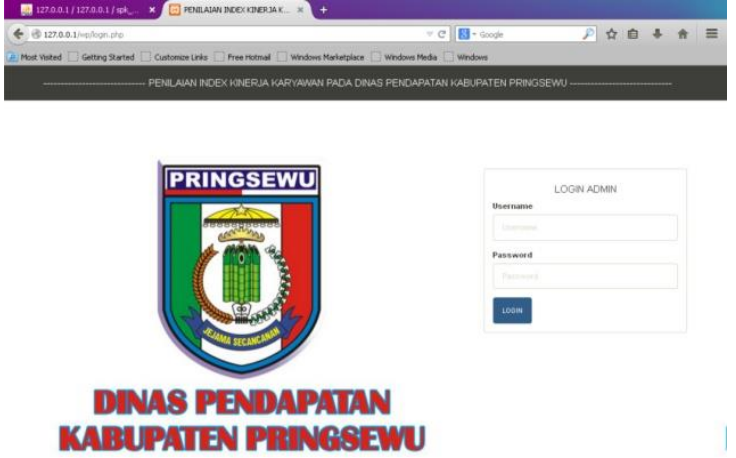

Fig. 1: Login page

\subsubsection{Employee data input page}

On the employee input data page the user can enter the employee name that has been determined for the process of decision making system of its performance appraisal. Display employee data input can be seen in the Figure 2 below.

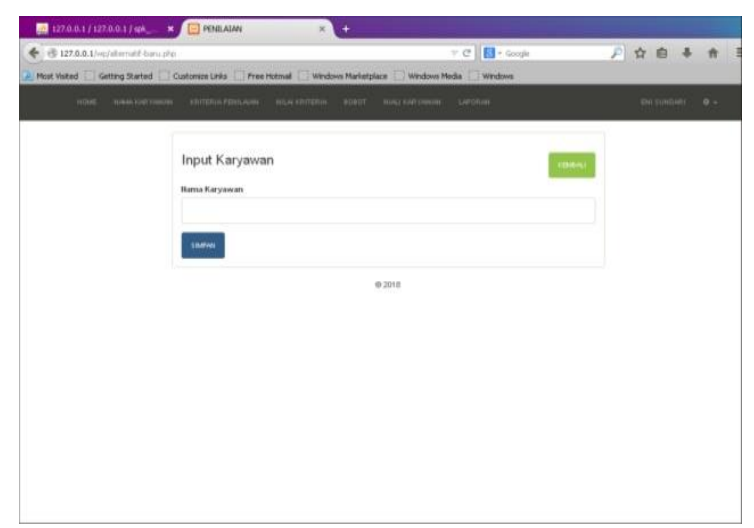

Fig. 2. Employee data input page

\subsubsection{Employee data page}

After the following employee data input is an employee data view as shown in Figure 3.

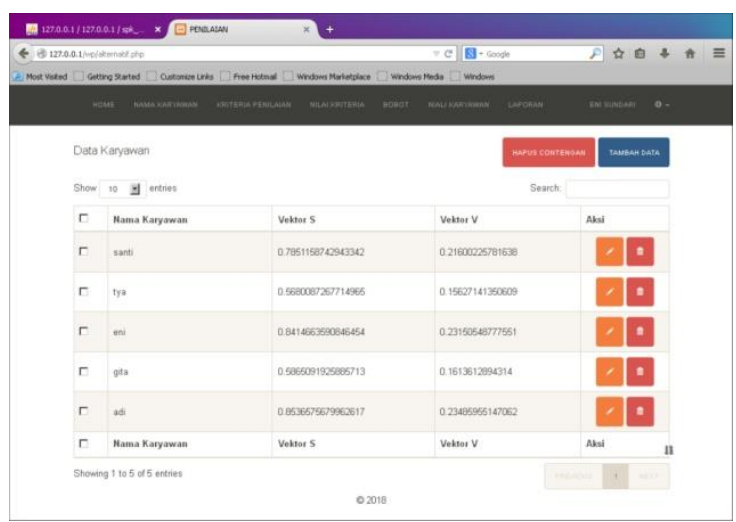

Fig. 3: Employee data page

\subsubsection{Preferences value data page}

The value data for employee performance appraisal process is shown in Figure 4.

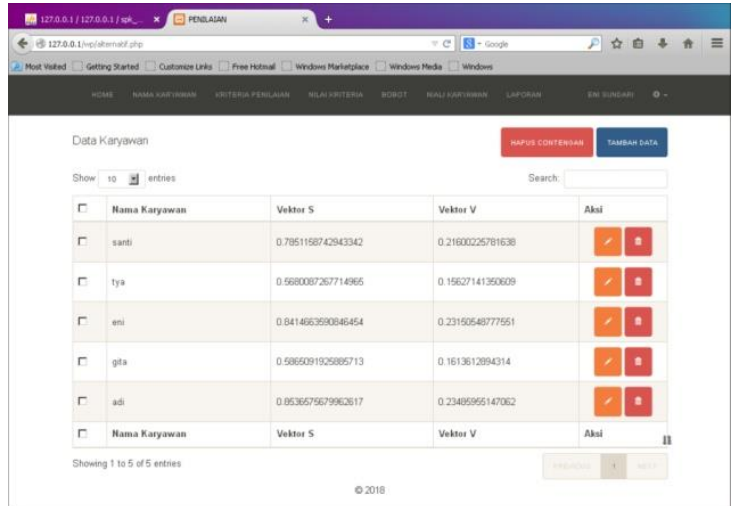

Fig. 4: Preferences value data page

\subsubsection{Performance appraisal page of employees}

It is the value of the inputs from the employee appraisal where the data is entered based on predetermined criteria through the calculation process is shown in Figure 5.

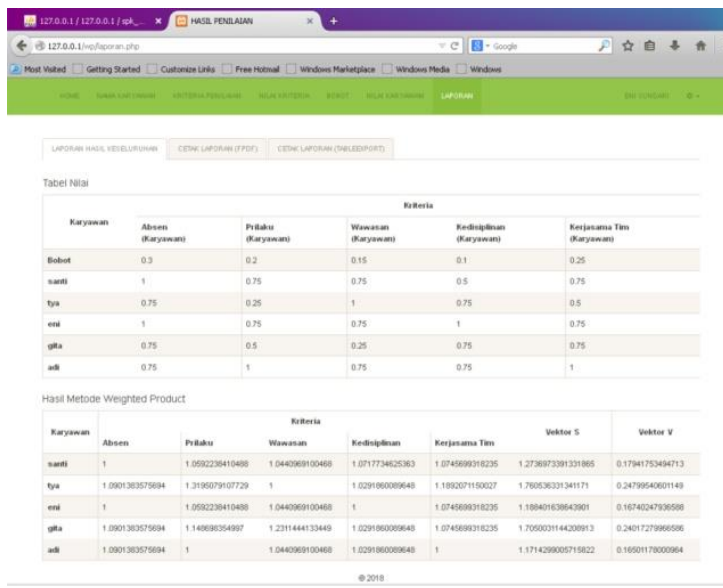

Fig. 5: Performance appraisal page of employees

\subsubsection{Page graph of the results of the assessment}

From the results of the following employee performance appraisal is a graph of the final result of the assessment of employee benefits is shown in Figure 6.

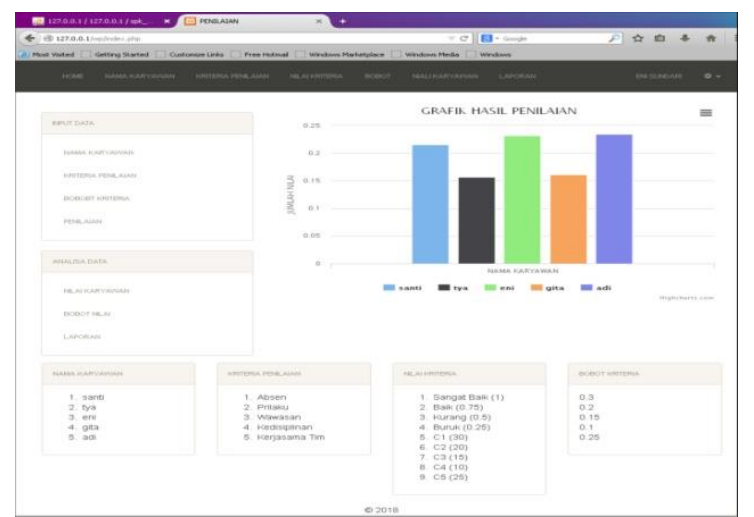

Fig. 6: Final result

Figure 6 shows Graph of the results of the decision making assessment of employee performance index on the revenue service. From the Table 7 below can be concluded that Adi has a very good value that is 0.250 followed by Eni with value 0.246 , followed by Santi with value 0,230 , followed by Tya with value 0,141 , and the last is Gita with value 0,133 . This research inspired 
by research related with fuzy logic and artificial intelligence [16] [61].

Table 7. employee performance appraisal analysis

\begin{tabular}{l|l|l|l}
\hline No & Name & Criterion value & Results \\
\hline 1 & Adi & Very Good & 0.250 \\
2 & Eni & Good & 0.246 \\
3 & Santi & good & 0.230 \\
4 & Tya & Less & 0.141 \\
5 & Gita & bad & 0.133 \\
\hline
\end{tabular}

\section{Conclusion}

This decision support system can perform the process of calculating employee performance appraisal with the best value results, so as to realize a fair assessment based on existing criteria calculated on this system using weighted product weighting (WP) that can produce the best employee performance appraisal system calculation from the highest value up to the lowest value. The highest score is the best employee while the lowest score is the worst employee performance. From the results of this system is needed by the leadership as a consideration in terms of promotion and salary increase this system can present employee performance appraisal reports quickly and clearly so that more effective and efficient. Based on the results of this study, for the development of decision-making systems performance appraisal index employees on the next revenue service is expected this system can make additional criteria as the development needs of users of the system so as to improve the performance of a good system

\section{References}

[1]. Saefudin and Wahyuningsih Sri, (2014). "Decision Support System For Employee Performance Appraisal Using Analytical Hierarchy Process Method (AHP) in RSUD Serang. " Journal Sistem Informasi. Vol . 1 No.1 2014. ISSN: 2406-7768

[2]. Nufus Hayatun, Dihardjo Soepeno Wudjud, and Solikin Agus, (2016) . " Employee performance appraisal using the method F uzzy simple Additive Weighted (FSAW ). " Journal of Mathematics Education, Science and Technology. Vol.1 No. 1, July 2016.Hal 125137

[3]. Agustin HandokoYoga, and Sulastri Sri, (2016). "The decision support system of employee performance appraisal for promotion in PD BPR ARTA SUKAPURA using Profile method Matching "Journal of VOI STMIK Tasikmalaya Vol. 5 , No. 2 (2016)

[4]. Rani Hangga Indria, and Mayasari mega, (2015). " The Effect of Performance Appraisal on Employee Performance With Motivation As a Moderation Variable." Vol.3 No.2 Hal: 164-170 (2015)

[5]. Sholikhun, (2017). " Comparison of Weighted Product Model And Weighted Sum Model In Selection Of Private College Best Computer Program." COMPUTER SCIENCE JOURNALS (CLICK) Volume 04, No 012017 HAL: 2406-7857.

[6]. Ebada Reham, Mesbah Saleh, Kosba Essam, and MaharKhaled, (2012). " A GIS-Based DSS for Evacuation Planning. " ICCTA 2012, 13-15 October 2012, Alexandria, Egypt.

[7]. Kusrini. (2007). Concepts And Applications Decision Support System. Yogyakarta: Andi Offset.

[8]. Niswatin Kumalasari Ratih, (2016) New Student Admission Selection System Using Medote Weighted Product (WP). SEMNASTEKNOMEDIA.

[9]. Muslihudin Muhamad, Kurniawan Didik, and W idyaningrum Ika, (2017). " Implementation of Fuzzy SAW Model in Assessment of Religious Extension Workers Performance." Vol. 8, No. 1 - ISSN: 2339-1103 Hal: 39-44

[10]. Ulfa Maria, (2015). "Analysis of employee performance measurement with Human Resources ScoreCard method at BMT Precious Metals "Vol. 3, No. December 2, 2015

[11]. K omariyah Siti, Yunus M Riza, and Rodiyansyah Fajar Sandi, (2016). "Fuzzy logic in decision-making system of scholarship acceptance."

[12]. Utari Wahyu Sri, and Utomo Setyo Fandy, (2011). "The performance decision support system works by Simple Additive Weighthing (SAW) method ." Vol. 4, No. February 1, 2011.

[13]. Farida Nur Intan Dan Sari Mustika Eka, (2016) Implementation of Weighted Product (WP) Method In Decision Support System New
Student Acceptance At UPTD SMA N 1 Gondang. SEMNASTEKNOMEDIA. AMIKOM Yogyakarta.

[14]. Esteriani Elita Sylvia, (2013 ). " Implementation of Weighted Product Method In Decision Selection Admission Professional Allowance Teachers Dikabupaten Ngawi " ENGINEERING INFORMATICS-S1 UNIVERSITY DIAN NUSWANTORO SEMARANG.

[15]. Bakar Abu, Rahma Maulida Latifa, Syukriyawati Gusnia, and Rahmadan Choirul M, (2014) "decision support system of employee bonus receipt using Weighted Product (WP) Method "

[16]. Maseleno, and M.M. Hasan, "Fuzzy Logic Based Analysis of the Sepak takraw Games Ball Kicking with the Respect of Player Arrangement," World Applied Programming Journal, vol. 2, no. 5, pp. 285-293, 2011.

[17]. A. Maseleno, and M.M. Hasan, "Finding Kicking Range of Sepak Takraw Game: A Fuzzy Logic Approach," Indonesian Journal of Electrical Engineering and Computer Science, vol. 14, no. 3, pp. 557-564, 2015.

[18]. A. Maseleno, and M.M. Hasan, Fuzzy logic and dempster-shafer theory to find kicking range of sepak takraw game. Proceedings of 5th International Conference on Computer Science and Information Technology (CSIT), 2013. Amman, Jordan, 8-12.

[19]. A. Maseleno, M.M. Hasan, M. Muslihudin, and T. Susilowati, "Finding Kicking Range of Sepak Takraw Game: Fuzzy Logic and Dempster-Shafer Theory Approach," Indonesian Journal of Electrical Engineering and Computer Science, vol. 2, no. 1, pp. 187-193, 2016.

[20]. A. Maseleno, and M.M. Hasan, "Dempster-shafer theory for move prediction in start kicking of the bicycle kick of sepak takraw game," Middle-East Journal of Scientific Research, vol. 16, no. 7, pp. 896-903, 2013.

[21]. A. Maseleno, and M.M. Hasan, "Move prediction in start kicking of sepak takraw game using Dempster-Shafer theory," Proceedings of International Conference on Advanced Computer Science Applications and Technologies (ACSAT). Kuala Lumpur, Malaysia, 376$381,2012$.

[22]. A. Maseleno, M.M. Hasan, N. Tuah, and M. Muslihudin, "Fuzzy Logic and Dempster-Shafer belief theory to detect the risk of disease spreading of African Trypanosomiasis," Proceedings of Fifth International Conference on Digital Information Processing and Communications (ICDIPC). University of Applied Sciences and Arts Western Switzerland (HES-SEO Valais Wallis), 2015, Switzerland, 153-158.

[23]. A. Maseleno, M.M. Hasan, N. Tuah, and C.R. Tabbu, "Fuzzy Logic and Mathematical Theory of Evidence to Detect the Risk of Disease Spreading of Highly Pathogenic Avian Influenza H5N1," Procedia Computer Science, 57, 348-357, 2015.

[24]. A. Maseleno, and G. Hardaker, "Malaria detection using mathematical theory of evidence," Songklanakarin Journal of Science \& Technology, vol. 38, no. 3, pp. 257-263, 2016.

[25]. A. Maseleno, and M.M. Hasan, "The Dempster-Shafer theory algorithm and its application to insect diseases detection," International Journal of Advanced Science and Technology, vol. 50, no. 1, pp. 111-119, 2013

[26]. A. Maseleno, and M.M. Hasan, "Poultry diseases warning system using dempster-shafer theory and web mapping," International Journal of Advanced Research in Artificial Intelligence, vol. 1,no. 3, 44-48, 2012.

[27]. A. Maseleno, and M.M. Hasan, "Skin diseases expert system using Dempster-Shafer theory,. International Journal of Intelligent Systems and Applications, vol. 4, no. 5, pp. 38-44, 2012.

[28]. A. Maseleno, and M.M. Hasan, "African Trypanosomiasis Detection using Dempster-Shafer Theory," Journal of Emerging Trends in Computing and Information Sciences, vol. 3, no. 4, pp. 480-487, 2012

[29]. A. Maseleno, and M.M. Hasan, "Avian influenza (H5N1) expert system using Dempster-Shafer theory," International Journal of Information and Communication Technology, vol. 4, no. 2, pp. 227$241,2012$.

[30]. A. Maseleno, Fauzi, and M. Muslihudin, "Ebola virus disease detection using Dempster-Shafer evidence theory," Proceedings of IEEE International Conference on Progress in Informatics and Computing (PIC). Nanjing, China, pp. 579-582, 2015.

[31]. A. Maseleno, and M.M. Hasan, "Skin infection detection using Dempster-Shafer theory," Proceedings of International Conference on Informatics, Electronics \& Vision (ICIEV). Dhaka, Bangladesh, 1147-1151, 2012.

[32]. A. Maseleno, and R.Z. Hidayati, "Hepatitis disease detection using Bayesian theory," In AIP Conference Proceedings. East Kalimantan, Indonesia, 050001-1 - 050001-10, 2017. 
[33]. A. Maseleno, M. Huda, M. Siregar, R. Ahmad, A. Hehsan, Z. Haroon, M.N. Ripin, S.S. Ikhwani, and K.A. Jasmi, (2017). Combining the Previous Measure of Evidence to Educational Entrance Examination. Journal of Artificial Intelligence, vol. 10, no. 3, pp. 8590, 2017.

[34]. M. Muslihudin, Fauzi, T.S. Susanti, Sucipto, A. Maseleno, "The Priority of Rural Road Development using Fuzzy Logic Based Simple Additive Weighting," International Journal of Pure and Applied Mathematics, vol. 118, no. 8, pp. 9-16, 2018.

[35]. R. Irviani, I. Dinulhaq, D. Irawan, R. Renaldo, Kasmi, A. Maseleno, "Areas Prone of the Bad Nutrition based Multi Attribute Decision Making with Fuzzy Simple Additive Weighting for Optimal Analysis," International Journal of Pure and Applied Mathematics, vol. 118, no. 7, pp. 589-596, 2018.

[36]. Fauzi, Nungsiyati, T. Noviarti, M. Muslihudin, R. Irviani, A. Maseleno, "Optimal Dengue Endemic Region Prediction using Fuzzy Simple Additive Weighting based Algorithm," International Journal of Pure And Applied Mathematics, vol. 118, no. 7, pp. 473-478, 2018

[37]. T. Susilowati, E.Y. Anggraeni, Fauzi, W. Andewi, Y. Handayani, A. Maseleno, "Using Profile Matching Method to Employee Position Movement," International Journal of Pure and Applied Mathematics, vol. 118, no. 7, pp. 415-423, 2018.

[38]. M. Muslihudin, Trisnawati, A. Latif, S. Ipnuwati, R. Wati, A. Maseleno, "A Solution to Competency Test Expertise of Engineering Motorcycles using Simple Additive Weighting Approach," International Journal of Pure and Applied Mathematics, vol. 118, no. 7, pp. 261-267, 2018.

[39]. Oktafianto, M.R. Al Akbar, Y. Fitrian, Zulkifli, Sodikin, Wulandari, A. Maseleno, "Dismissal Working Relationship using Analytic Hierarchy Process Method," International Journal of Pure and Applied Mathematics, vol. 118, no. 7, pp. 177-184, 2018.

[40]. W. Waziana, R. Irviani, I. Oktaviani, F. Satria, D. Kurniawan, A. Maseleno, Fuzzy Simple Additive Weighting for Determination of Recipients Breeding Farm Program, International Journal of Pure and Applied Mathematics, vol. 118, no. 7, pp. 93-100, 2018.

[41]. S. Mukodimah, M. Muslihudin, Fauzi, A. Andoyo, S. Hartati, A. Maseleno, "Fuzzy Simple Additive Weighting and its Application to Toddler Healthy Food," International Journal of Pure and Applied Mathematics, vol. 118, no. 7, pp. 1-7, 2018.

[42]. A. Maseleno, M. Huda, K.A. Jasmi, B. Basiron, I. Mustari, A.G. Don, R. Ahmad, "Hau-Kashyap Approach for Student's Level of Expertises," Egyptian Informatics Journal, 2018.

[43]. EPhzibah, E. P., \& Sujatha, R. (2017). Big data management with machine learning inscribed by domain knowledge for health care. International Journal of Engineering \& Technology, 6(4), 98-102.

[44]. Castaño, V. M., Rangel-Miranda, D., Alaniz-Lumbreras, D., \& Olvera-Gonzálezb, E. (2014). Fuel flow control through a fuzzy servomechanism: a comparative analysis. International Journal of Engineering \& Technology, 3(4), 506.

[45]. M. Karthikeyan, S.M.V. Pandian. Optimum Distribution of Power by Intelligent Fuzzy Sets Analyzer and Controller. International Journal of Engineering \& Technology, 7(2.24), 263-266, 2018. doi:http://dx.doi.org/10.14419/ijet.v7i2.24.12061

[46]. Rathaiah, M., Ram Kishore Kumar Reddy, P., \& Sujatha, P. (2018). Adaptive Fuzzy Controller Design for Solar And Wind Based Hybrid System. International Journal of Engineering \& Technology, 7(2.24), 283-290. doi:http://dx.doi.org/10.14419/ijet.v7i2.24.12065

[47]. Fitria Jumarni, R., \& Zamri, N. (2018). An integration of fuzzy TOPSIS and fuzzy logic for multi-criteria decision making problems. International Journal of Engineering \& Technology, 7(2.15), 102-106. doi:http://dx.doi.org/10.14419/ijet.v7i2.15.11362

[48]. Elavarasu, R., \& Christober Asir Rajan, C. (2018). Closed loop Fuzzy Logic Controlled Interleaved DC-to-DC converter Fed DC Drive System. International Journal of Engineering \& Technology, 7(2.24), 397-403. doi:http://dx.doi.org/10.14419/ijet.v7i2.24.12120

[49]. P. Varghese, M., \& Amudha, A. (2018). Hybrid harmony search algorithm \& fuzzy logic for solving unit commitment problem with wind power uncertainty. International Journal of Engineering \& Technology, 7(1.9), 75-83. doi:http://dx.doi.org/10.14419/ijet.v7i1.9.9837

[50]. Shanmugan, S., P, S., Karthickeyan, M., Saravanan, A., Akash Kanna, G., \& Ranjith Raja, V. (2018). Formation and speciation of Sullage Water Natural Conduct analysis of Fuzzy logic Application by Solar Distillation.International Journal of Engineering \& Technology, $7(2.24)$ 444-447. doi:http://dx.doi.org/10.14419/ijet.v7i2.24.12131

[51]. Suruthi, N., Saranya, R., Subashini, S., Shanthi, P., \& Umamakeswari, A. (2018). Managing Irrigation in Indian Agricul- ture Using Fuzzy Logic - A Decision Support System. International Journal of Engineering \& Technology, 7(2.24), 321-325. doi:http://dx.doi.org/10.14419/ijet.v7i2.24.12075

[52]. Rani, U., Dalal, S., \& Kumar, J. (2017). Optimizing performance of fuzzy decision support system with multiple parameter dependency for cloud provider evaluation. International Journal of Engineering $\begin{array}{lll}\& & \text { Technology, } & 7(1.2),\end{array}$ doi:http://dx.doi.org/10.14419/ijet.v7i1.2.9044

[53]. Kumar Dutta, A. (2018). Computing with words using intuitionistic fuzzy logic programming. International Journal of Engineering \& Technology, $\quad 7(1.9)$, doi:http://dx.doi.org/10.14419/ijet.v7i1.9.9815

[54]. Ramakrishnan, S., \& Prayla Shyry, S. (2017). Distributed fuzzy logic based cluster head election scheme (DFLCHES) for prolonging the lifetime of the wireless sensor network. International Journal of Engineering \& Technology, 7(1.5), 111-117. doi:http://dx.doi.org/10.14419/ijet.v7i1.5.9131

[55]. Kiran Kumar, M., Almaj, S., \& S. Srikanth, K. (2018). An improved 1- $\varphi$ rectifier system using fuzzy logic control with 3- $\varphi$ variable frequency drive. International Journal of Engineering \& Technology, 7(2.7), 520-525. doi:http://dx.doi.org/10.14419/ijet.v7i2.7.10875

[56]. Vishnuram, P., Nagarajan, B., \& Sureshkumar, A. (2017). Investigations on stability and performance of a varia-ble frequency based fuzzy logic controller for induction cooking system. International Journal of Engineering \& Technology, 7(1.2), 15-22. doi:http://dx.doi.org/10.14419/ijet.v7i1.2.8970

[57]. Jaswini Sarwade, T., S. Jape, V., \& G. Bharadwaj, D. (2018). Power quality problems mitigation using dynamic voltage restorer (DVR) with pi controller and fuzzy logic controller. International Journal of Engineering \& Technology, 7(2.12), 214-218. doi:http://dx.doi.org/10.14419/ijet.v7i2.12.11282

[58]. S.Srivatchan, N., \& P.Rangarajan, D. (2018). Harmonic reduction in a renewable energy islanded microgrid with fuzzy PID controller. International Journal of Engineering \& Technology, 7(2.12), 380-385. doi:http://dx.doi.org/10.14419/ijet.v7i2.12.11355

[59]. K, Reena and Venkatesh, V. (2018). Intelligent Decision Support System for Home Automation - ANFIS Based Approach. International Journal of Engineering \& Technology, 7(2.24), 421-427. doi:http://dx.doi.org/10.14419/ijet.v7i2.24.12127

[60]. Antic, R., Cvetkovic, S., Pejovic, B., \& Cvetkovic, M. (2013). Definition of manufacturability - product of mathematical expressions and fuzzy logic for his early design. International Journal of Engi-

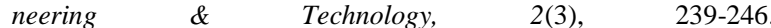
doi:http://dx.doi.org/10.14419/ijet.v2i3.1082

[61]. Sarath kumar, A., Durga Kaveri, M., B.V Bhargavi, K., Naga Swetha, N., \& Priyanka, K. (2018). Efficient Routing In Wsn Using Enhanced Fuzzy Logic. International Journal of Engineering \& Technology, 7(2.17), doi:http://dx.doi.org/10.14419/ijet.v7i2.17.11719 